\title{
APOTEOZA SOCIJALNE DRŽAVE: IMPERATIVNI ZAHTJEV OSTVARENJA SOCIJALNE PRAVDE U REPUBLICI HRVATSKOJ***
}

Sažetak: $\quad$ Izborom hrvatskog ustavotvorca, u Ustav Republike Hrvatske unesena su sva jamstva gospodarskih, socijalnih i kulturnih prava zajamčena ustavima razvijenih europskih demokracija i Međunarodnim paktom o ekonomskim, socijalnim i kulturnim pravima, a kojeg je Republika Hrvatska stranka. Time je stvorena dvostruka (ustavna i međunarodna) obveza hrvatskog zakonodavca na uspostavu socijalno pravednoga poretka. Iako ustavni tekst smješta obje generacije ljudskih prava u istu glavu Ustava, u ustavnosudskoj praksi izvedeno je shvaćanje kako socioekonomska prava ne pripadaju u sferu organskog zakonodavstva kojim se razrađuju Ustavom zajamčena ljudska prava i temeljne slobode. Unatoč tome, mogućnost njihove ustavnosudske zaštite nije onemogućena te je Ustavni sud razvio impozantan niz doktrinarnih razmatranja o prirodi socijalnih prava, iskazujući predanost konceptu socijalne države kao fundacijskom elementu europskog konstitucionalizma. Ipak, valja istaknuti pasivnost Ustavnog suda prema političkim granama vlasti glede socijalne materije te pledirati za zauzimanje aktivnijeg stava $\mathrm{u}$ tom pogledu.

Ključne riječi: $\quad$ socijalna država, socijalna pravda, ljudska prava, Ustav Republike Hrvatske, Ustavni sud Republike Hrvatske

\footnotetext{
Valentino Kuzelj, student Pravnog fakulteta Sveučilišta u Zagrebu, Trg Republike Hrvatske 14, 10000 Zagreb. E-adresa: valentino.kuzelj01@gmail.com. ORCID: https://orcid.org/0000-0003-3028-8562.

** Dr. sc. Sonja Cindori, izvanredna profesorica Pravnog fakulteta Sveučilišta u Zagrebu, Trg Republike Hrvatske 14, 10000 Zagreb. E-adresa: sonja.cindori@pravo.hr. ORCID: https://orcid.org/0000-0002-0134-9285.

*** Dr. sc. Ana Horvat Vuković, izvanredna profesorica Pravnog fakulteta Sveučilišta u Zagrebu, Trg Republike Hrvatske 14, 10000 Zagreb. E-adresa: ana.horvat@pravo.hr. ORCID: https://orcid.org/0000-0002-8451-5620.

**** Ovaj je rad dijelom temeljen na radu Valentina Kuzelja "Apoteoza socijalne države: ustavno-identitetska ukorijenjenost $i$ imperativni zahtjev ostvarenja socijalne pravde”, izrađenom pod mentorstvom izv. prof. dr. sc. Ane Horvat Vuković i izv. prof. dr. sc. Sonje Cindori te nagrađenom Dekanovom nagradom Pravnog fakulteta Sveučilišta u Zagrebu za ak. god. 2019./2020.
} 


\section{UVODNE NAPOMENE}

Industrijsko društvo na prijelazu 19. i 20. stoljeća, obilježeno socijalnim izrabljivanjem kao posljedicom supstancijalne nejednakosti, zahtijeva preispitivanje i svojevrsni socijalni ispravak temeljnih postulata liberalnog individualizma. ${ }^{1}$ Iz tog zahtjeva razvijaju se rudimentarni oblici socijalnog osiguranja te začetak ideje o socijalnoj državi. ${ }^{2}$ Zadaće postavljene pred socijalnu državu podrazumijevaju zaštitu i unaprjeđenje životnog standarda građana preko koordiniranih institucionalno-normativnih mjera, obuhvaćaju temeljna ljudska prava i socijalno tumačenje subjektivnih prava $^{3}$ te pretpostavljaju ustavno utemeljenje prava na jednakost i život dostojan čovjeka, shvaćenih kao ostvarenje socijalne jednakosti, tj. socijalne slobode. ${ }^{4}$ Jednako kako je razvoj socijalne države potekao iz stvarnosti društvenih odnosa, tako Miličić smatra da izvorište i opravdanje temeljnih ljudskih prava (među koja nedvojbeno pripadaju i socioekonomska prava) treba tražiti u slojevitosti čovjekovih potreba. ${ }^{5}$ Zbog takvog razvoja, koji afirmira građane prema državi postavljajući joj zahtjev pozitivnog djelovanja u cilju ostvarenja širih društvenih interesa, dolazi do pomicanja klatna legitimnosti te interesi dobrobiti građana postaju sastavnim dijelom legitimiteta političke vlasti. Posljedično se proširuje spektar državnog djelovanja te se pred nju postavlja zahtjev osiguranja javnih službi. ${ }^{6}$ Time generiran porast državnog upravnog aparata i povezanih troškova nameće pitanje nužnosti pružanja socijalne sigurnosti od strane države. Na to pitanje Pusić nedvosmisleno odgovara kako "samo onaj organ u društvu kojem je povjereno donošenje kolektivno obvezatnih odluka, a to je država, može donositi i odluke o preraspodjeli društvenog dohotka". ${ }^{7}$

U skladu s time, država 19. i 20. stoljeća definirala se organizacijom i uvećanjem mreža javnih službi, kreiranjem pravnog okvira djelovanja civiliziranog društva, regulacijom društvenih i ekonomskih aktivnosti i ostvarenjem sustava socijalne sigurnosti od životnih rizika. Iako je većina tih mjera isprva pripadala programima lijevih stranaka, ${ }^{8}$ nakon Drugog svjetskog rata ideja socijalne pravednosti postaje općeprihvaćenom civilizacijskom vrijednošću. Tako izražene zadaće suvremene države i posljedični porast državnog upravnog aparata, šireći bazu legitimnosti socijalnih demokratskih poredaka, rezultiraju povećanim potrebama na prihodovnoj strani proračuna. Ekonomske krize 70-ih godina 20. stoljeća, zbog smanjene mogućnosti financiranja i pružanja usluga socijalne države, za posljedicu imaju preispitivanje njezina legitimiteta. Neoliberalna paradigma je, kao odgovor na nastalu krizu, odrekla legitimnost socijalnim funkcijama države, nastojeći oživjeti duh liberalnog individualizma fiskalno neutralnim i nesocijalnim mjerama porezne politike te liberalizacijom, privatizacijom, dere-

1 Berislav Perić, Struktura prava (Informator 1994) 212-213.

2 O uvođenju mjera socijalnog osiguranja te nastanku i različitoj dinamici razvoja pojedinih modela socijalnih država vidi Sonja Cindori i Valentino Kuzelj, 'Exemplis discimus: Reafirmacija vrijednosti i redefinicija sadržaja socijalne države u novom stoljeću' (2019) 40(2) Zbornik Pravnog fakulteta Sveučilišta u Rijeci 825-828; Aart De Geus, Eric Thode i Christiane Weidenfeld, Europe Reforms Labour Markets: Leaders' Perspectives (De Gruyter 2016) 4-8.

3 Duško Vrban, Država i pravo (Golden marketing 2003) 203.

4 Ibid 205.

5 Vjekoslav Miličić, Opća teorija prava i države (Vlastita naklada 2008) 214.

6 Eugen Pusić, Upravne organizacije: interakcija - struktura - interes (Društveno veleučilište u Zagrebu 2005) 102.

7 Ibid 104.

8 Eugen Pusić, 'Odnos ljevice prema državi' (1996) 33(2-3) Politička misao 49-50. 
gulacijom i marketizacijom javnih službi u okviru doktrine novog javnog menadžmenta (engl. new public management). ${ }^{9}$ Jedina razlika je što se težište takve politike premješta, zbog čega najveća važnost ostvarenja individualne slobode kao maksime klasičnog liberalizma ustupa mjesto najvećoj važnosti osiguranja prava vlasništva i maksimizacije profita.

Kraj blokovskih sukoba, informacijska revolucija i proces globalizacije na prijelazu milenija dovode do preispitivanja koncepta moderne države. Fukuyama proglašava "smionu pobjedu ekonomskog i političkog liberalizma" te "...univerzalizacij[u] zapadne liberalne demokracije kao završnog oblika ljudske vladavine”. ${ }^{10}$ Znakovito je, iako možda sasvim nesvjesno, što u rečeničnoj konstrukciji ekonomski liberalizam stavlja ispred političkog, s obzirom na to da su naredna desetljeća ukazala na krhkost liberalne demokracije i nužnost proaktivnog djelovanja (i na socijalnom planu) u svrhu njezina očuvanja, dok se neoliberalna ideologija, unatoč cikličkim krizama kapitalizma, pokazala neupitnom. To proizlazi iz asimetričnog odnosa demokracije i kapitalizma, s obzirom na to da se tržišno gospodarstvo smatra preduvjetom demokracije, ali ne i vice versa, dok je budućnost demokracije vezana uz stabilnost saveza demokratske i ustavne države te tržišne privrede. ${ }^{11}$

Ne čudi stoga što je 21. stoljeće otvorilo raspravu o krizi samog koncepta moderne države i njezine suverenosti. Značajnom kritikom njegovoj održivosti valja istaknuti činjenicu suženog manevarskog prostora parlamenata u vođenju financijske politike, što proizlazi iz zadatosti većine izdataka, državne zaduženosti te procesa deregulacije i privatizacije koji umanjuju mogućnosti parlamentarnog nadzora. ${ }^{12}$ Pritom su kreatori državnih politika suočeni s desolidarizacijom društva te proturječnošću "pojačanih društvenih zahtjeva prema državi i sve manje spremnosti da za to stavi na raspolaganje potrebna sredstva”. ${ }^{13}$ Nadalje, globalizacijski proces, najdosljednije proveden u svojem čistom ekonomskom obličju umreženosti svjetskoga tržišta, negira mogućnost vođenja izolirane državne gospodarske politike, ostavljajući joj ograničen spektar mjera utjecaja na ponašanje i izglede privrednih aktera. ${ }^{14}$

Grande pak upozorava kako ne treba podcijeniti mogućnosti nacionalne države, ističući kako ona "još uvijek posjeduje velike prostore djelovanja u bitnim, ekonomskom globalizacijom zahvaćenim područjima politike kao što su ekonomska, socijalna i ekološka politika" te da "može koristiti te kapacitete djelovanja za postizanje središnjih ciljeva demokratske države dobrobiti". ${ }^{15}$ Takvi stavovi, iako naizgled oprečni, nipošto nisu međusobno isključivi. Promatrani zajedno, navode na zaključak kako je novo tisućljeće izmijenilo instrumente moderne države te je svjetska umreženost dovela do slabljenja odrednica državne suverenosti u njihovu izvornom, represivnom obličju. Naprotiv, ciljevi države dobrobiti, zbog cikličkih kriza kapitalizma, dobivaju priliku nanovo se legitimirati. Valja imati na u umu da je legitimnost prava,

9 O reformama javne uprave pod utjecajem teorije novog javnog menadžmenta vidi Ivan Koprić i drugi, Upravna znanost: javna uprava u suvremenom europskom kontekstu (Pravni fakultet Sveučilišta u Zagrebu: Studijski centar za javnu upravu i javne financije 2014) 347-355.

12 Wolfgang Reinhard, 'Čemu nas o budućnosti države poučava njezina povijest?' (2002) 39(2) Politička misao 23.

13 Rüdiger Voigt, 'Koliko nam države treba?' (2002) 39(2) Politička misao 33-34. 
kao "svjesno i dobrovoljno prihvaćanje poretka (od, op. a.) onih na koje se norme i pravila poretka odnose" sa svrhom "stabilizacij[e] normativnih očekivanja pojedinca i društva", promjenjiv i dinamičan proces te plod povijesnog razvitka. ${ }^{16}$ Upravo u suvremenosti, nejednakosti pojačane procesima globaliziranog tržišta apostrofiraju ulogu nacionalnih socijalnih država pri ublažavanju negativnih socijalnih efekata globalizacijskog procesa i ekonomskih kriza. Socijalnu državu moguće je promatrati kao stabilizirajući faktor pri ublažavanju ekonomskih posljedica krize. Pritom se, nasuprot potencijalno pozitivnom učinku mjera "države dobrobiti" u olakšavanju položaja građana, nameće činjenica ograničenog manevarskog prostora u vođenju socijalnih politika, kao posljedica (u pojedinim državama) dugogodišnjeg deficita javnog sektora i povećanja javnog duga. Nedostatnost sredstava financiranja mjera socijalne politike naglašava opasnost da socijalna država postane kolateralnom žrtvom smanjenja fiskalnog deficita snižavanjem razine i opsega socijalne zaštite. Kao treća mogućnost (umjesto zaduživanja ili smanjenja socijalnih benefita) ističe se potreba povećanja javnih prihoda. U tom je smislu potrebna promjena javnog diskursa o ulozi poreza, koje ne treba promatrati kao teret, već prepoznati potencijal poreznog sustava kao nositelja rješenja. ${ }^{17}$

U skladu s time, potencijalnu desolidarizaciju (dijela) društva valja promatrati u svakom društvu (državi) zasebno, s obzirom na povijesne, društvene, ekonomske i političke prilike te na stupanj društvenog konsenzusa (koji se pri svakoj krizi iznova postiže) o poželjnom stupnju aktivnosti države na gospodarskom i socijalnom planu te količini sredstava koju su građani preko poreza, u svrhu financiranja mjera socijalne politike, spremni izdvojiti. Upravo zbog nestalnosti sadržaja i promjenjivosti opsega mjera socijalne države, nužno je zagledati se u minimum zahtjeva socijalne pravde koji suvremeni ustavi, u sprezi s prihvaćenim međunarodnim standardima socijalne sigurnosti, postavljaju kao imperativ pred nositelje javnih vlasti. S time na umu, ovaj rad postavlja tri teze. Prva ističe da osiguranje (minimuma) socijalne sigurnosti građana predstavlja ustavnu i međunarodnu obvezu postavljenu pred hrvatskog zakonodavca. Druga dokazuje kako je u hrvatskoj ustavnosudskoj praksi potvrđen obvezujući značaj koncepta socijalne države, načela socijalne pravde i ustavnih socijalnih prava. Treća ukazuje na, unatoč doktrinarnoj predanosti konceptu socijalne države, pretjeranu pasivnost Ustavnog suda prema političkim granama vlasti (ponajprije zakonodavnoj) u vezi sa socijalnom materijom. Stoga se u drugom poglavlju ispituje narav prava na socijalnu sigurnost prepoznatog u Općoj deklaraciji o ljudskim pravima i Međunarodnom paktu o ekonomskim, socijalnim i kulturnim pravima te se ističe važnost mogućnosti (ustavno)sudske zaštite socijalnih prava. U trećem se poglavlju izlaže utemeljenje socijalnih prava u hrvatskom Ustavu i njihova pripadnost temeljnim ljudskim pravima i slobodama. Ukazuje se na (prijeporno) razlikovanje osobnih i političkih te socijalnih, ekonomskih i kulturnih prava izvedeno u praksi hrvatskog Ustavnog suda u vezi sa zakonskim oblikom razrade socijalnih prava. Pritom se apostrofira kako navedeno razlikovanje ne utječe na jednaku mogućnost ustavnosudske zaštite potonjih, već dodatno naglašava njezinu nužnost. Potom se prikazuje evolucija hrvatske ustavnosudske prakse u odnosu na klauzulu socijalne države, načelo socijalne pravde te ustavna socijalna prava. Umjesto zaključka, pledira se za konačno napuštanje stava pasivnosti prema političkim granama vlasti te zauzimanje aktivnije uloge Ustavnog suda u zaštiti socijalnih prava.

16 Josip Kregar, 'Legitimnost prava' (2011) 5(1) Studia lexicographica 20.

17 Vidi Bent Greve, 'Future of the welfare state?' in Bent Greve (ed), Routledge Handbook of the Welfare State (2nd edn, Routledge 2019) 527. 


\section{SOCIJALNA SIGURNOST KAO PREDUVJET LJUDSKOG DOSTOJANSTVA I NORMATIVNI ZAHTJEV SUVREMENIH DEMOKRACIJA}

U prilog shvaćanju kako socijalna i ekonomska prava ne mogu biti promatrana odvojeno od općeg narativa o temeljnim ljudskim pravima govori činjenica da ih je, nakon njihova inicijalnog razvoja koncem 19. i u prvoj polovici 20. stoljeća, Opća deklaracija o ljudskim pravima (u nastavku: Opća deklaracija) Ujedinjenih naroda (u nastavku: UN) 1948. godine priznala zajedno s političkim i građanskim pravima te je upravo djelovanje UN-a dalo snažan poticaj njihovu širenju preko nacionalnih i međunarodnih propisa. ${ }^{18}$ Priznajući urođenu vrijednost dostojanstva te jednakih i neotuđivih prava svih ljudi (preambula; čl. 1.) te pravo svakog čovjeka na socijalnu sigurnost i "na ostvarenje ekonomskih, socijalnih i kulturnih prava neophodnih za njegovo dostojanstvo i slobodan razvoj njegove osobnosti putem državnih napora i međunarodne suradnje te u skladu s organizacijom i mogućnostima svake pojedine države" (čl. 22.) ${ }^{19}$ Opća deklaracija čini konačan odmak od shvaćanja slobode kao krajnjeg individualizma klasične liberalne teorije.

Vrijednosna predanost Opće deklaracije ljudskom dostojanstvu i socijalnoj slobodi svoj je pravno-obvezujući odraz dobila u odredbama Međunarodnog pakta o ekonomskim, socijalnim i kulturnim pravima ${ }^{20}$ (engl. International Covenant on Economic, Social and Cultural Rights, u nastavku: ICESCR). Tumačenja odredbi ICESCR-a sadržana u tzv. općim primjedbama (engl. General Comments) Odbora za ekonomska, socijalna i kulturna prava ${ }^{21}$ (engl. Committee on Economic, Social and Cultural Rights, u nastavku: CESCR) pomažu pri razumijevanju obveza država stranaka te ujedno djeluju kao smjernice (ustavnim) sudovima u kreiranju nacionalnih jurisprudencija socioekonomskih prava. U prilog univerzalnosti zajamčenih prava govori politička i ekonomska neutralnost ICESCR-a, ne priklanjajući se ni jednom političkom ili ekonomskom sustavu, pod uvjetom da je isti demokratski i poštuje ljudska prava. ${ }^{22}$ Tako je jasnijem definiranju obveze poduzimanja mjera, do maksimuma raspoloživih sredstava, radi progresivnog ostvarenja priznatih prava u cilju postizanja pune realizacije ${ }^{23}$ poslužila Opća primjedba br. 3. Njome je potvrđeno kako zajamčena prava ne predstavljaju tek neobvezujuće smjernice kreatorima socijalne politike te se ističe dužnost država na poduzimanje pravovremenih i učinkovitih mjera, zabrana usvajanja regresivnih mjera te obveza osiguranja minimalne jezgre sadržanih prava. Pritom neuspjeh u osiguranju minimuma prava konstituira prima facie neispunjenje obveza proizišlih iz ICESCR-a te čak i ako su raspoloživa sredstva očigledno nedostatna, država mora težiti najvećem mogućem ostvarenju prava u danim okolnostima. ${ }^{24}$

\footnotetext{
18 Dennis M Davis, 'Socio-economic Rights' in Michel Rosenfeld and András Sajó (eds), The Oxford Handbook of Comparative Constitutional Law (OUP 2012) 1020-1022.

19 Tekst Opće deklaracije vidi u Odluci o objavi Opće deklaracije o ljudskim pravima (NN-MU 12/2009) (HR).

20 International Covenant on Economic, Social and Cultural Rights, (1983) UNTS vol 993.

21 O sastavu i djelovanju vidi Juraj Andrassy i drugi, Međunarodno pravo, vol 1 (Školska knjiga 2010) 374.

22 CESCR General Comment No 3: The Nature of States Parties' Obligations (art 2 para 1 of the Covenant), 14 December 1990 E/1991/23, para 8

23 ICESCR (n 20) art 2, para 1. 
Značaj navedenih obveza posebno je naglašen kad je riječ o pravu na socijalnu sigurnost ${ }^{25}$ koje se smatra ključnim za ostvarenje ljudskog dostojanstva te, zahvaljujući svojem redistributivnom karakteru, pridonosi smanjenju siromaštva i unaprjeđenju socijalne uključenosti. ${ }^{26}$ Uvažavajući činjenicu značajnog fiskalnog tereta generiranog mjerama socijalne sigurnosti, CESCR ponavlja fundamentalnu važnost socijalne sigurnosti u ostvarenju ljudskog dostojanstva te ističe prioritet njezine realizacije. Naglašava "čvrstu presumpciju” zabrane usvajanja mjera s regresivnim učinkom te, ako bi takve mjere bile usvojene, teret dokazivanja nužnosti, opravdanosti i nedostatka alternative njihovu uvođenju. ${ }^{27}$ Iako nisu apsolutno zabranjene, regresivne mjere podložne su strogoj ocjeni vlastite opravdanosti. Landau upozorava kako su takve mjere rijetko usmjerene na rastakanje socijalne sigurnosti najsiromašnijih društvenih slojeva, već da je češće riječ o smanjenju prava pripadnika srednjeg i višeg društvenog sloja (npr. javnih službenika). Stoga smatra kako bi CESCR trebao ublažiti ili napustiti načelo ne-regresivnosti. S druge strane, ističe važnost načela osiguranja minimalne jezgre prava, smatrajući ga jamcem ostvarenja dostojanstva upravo najsiromašnijih skupina. ${ }^{28}$

Uz usvajanje zakonskih i drugih mjera, CESCR sudsku zaštitu smatra prikladnim sredstvom za ostvarenje prava, u skladu s pravilima nacionalnog pravnog poretka te nabraja set neposredno primjenjivih prava. ${ }^{29}$ Iako pravo na djelotvorno pravno sredstvo ne znači isključivo sudsku zaštitu, ona postaje nužna ako se pojedino pravo iz ICESCR-a ne bi moglo (učinkovito) ostvariti drugim pravnim sredstvima. Ne umanjujući kompetencije zakonodavne i izvršne vlasti, izuzimanje ekonomskih i socijalnih prava iz sudske nadležnosti bilo bi nespojivo s načelom isprepletenosti i međuovisnosti dviju generacija ljudskih prava (političkih i građanskih te ekonomskih, socijalnih i kulturnih) te bi značajno ograničilo mogućnost sudske zaštite najugroženijih društvenih skupina. ${ }^{30}$ Takvim je rezoniranjem CESCR potvrdio mogućnost sudskog ostvarenja (engl. justiciability) ekonomskih, socijalnih i kulturnih prava, odričući valjanost prigovoru kako su ista neodvojivo povezana uz preraspodjelu resursa i samim time inherentno politička pitanja te ne pripadaju u nadležnost sudova. ${ }^{31}$

Unatoč svojevrsnom normativnom optimizmu tvoraca ICESCR-a, tradicionalno razlikovanje dviju generacija prava i mogućnosti njihove sudske zaštite pokazalo se otpornijim te je priznanje socijalnih i ekonomskih prava pred nacionalnim sudovima teklo nešto sporije. Davis navodi primjere njemačkog Saveznog ustavnog suda te indijskog Vrhovnog suda koji su tijekom 70-ih godina donijeli pionirske odluke u vezi s priznanjem ustavnih socijalnih prava. Ipak, napominje da je do 90-ih godina međunarodnopravni pristup počeo utjecati na nacionalne pravne sustave te kako ne čudi da je većina država koje su u to vrijeme prolazile demokratsku tranziciju u svoje ustave uključila jamstva socijalnih i ekonomskih prava prihvaćajući, eksplicite ili kroz sudsku praksu, pristup izložen u Općoj primjedbi br. $3 .^{32}$ Valja naglasiti

$25 \quad$ ICESCR (n 20) art 9.

26 CESCR General Comment No 19: The right to social security (art 9), 4 February 2008, E/C.12/GC/19, para 1, 3.

27 Ibid para 41-42.

28 David Landau, 'The Reality of Social Rights Enforcement' (2012) 53(1) Harvard International Law Journal 240-241.

29 CESCR (n 22) para 5.

30 CESCR General Comment No 9: The domestic application of the Covenant, 3 December 1998, E/C.12/1998/24, para 9-10.

31 Evadne Grant, 'Human Dignity and Socio-Economic Rights' (2012) 33(3) Liverpool Law Review 244.

32 Dennis M Davis, 'Socio-economic rights: has the Promise of Eradicating the Divide Between First and Second Generation Rights Been Fulfilled?' in Tom Ginsburg and Rosalind Dixon (eds), Comparative Constitutional Law (Edward Elgar 2011) 520. 
da, iako međunarodni standardi igraju važnu ulogu u procjeni sustava socijalne sigurnosti te unatoč činjenici da se u globalnim (ponajprije u Međunarodnoj organizaciji rada) i europskim (pod okriljem Vijeća Europe i Europske unije) okvirima usvajaju instrumenti zaštite socijalne sigurnosti, socijalna prava tek trebaju dobiti učinkovit sustav zaštite na međunarodnom planu. Posljedično, njihovo ostvarenje uvelike ostaje u domeni nacionalnog sustava socijalne sigurnosti. ${ }^{33}$ Stoga i CESCR, iako ne postoji obveza inkorporacije odredaba ICESCR-a u pravne poretke država stranaka, potiče takav pristup u cilju olakšanja zaštite prava pred nacionalnim sudovima. ${ }^{34}$ Tako su svjesnim izborom hrvatskog ustavotvorca prihvaćena sva gospodarska, socijalna i kulturna prava zajamčena ustavima razvijenih europskih demokracija te su pritom u Ustav Republike Hrvatske (u nastavku: URH) ${ }^{35}$ unesena sva prava iz ICESCR-a, ${ }^{36}$ kojeg je Republika Hrvatska i formalno postala strankom na temelju notifikacije o sukcesiji ${ }^{37}$ od 8 . listopada 1991. godine. Time je stvorena dvostruka obveza (ustavna i međunarodna) hrvatskog zakonodavca na kreiranje socijalno pravednoga poretka.

\subsection{JAMSTVO I ZAŠTITA SOCIJALNIH PRAVA U SUVREMENIM USTAVIMA}

Suvremenim europskim socijalnim državama, uz dužnost poštovanja individualne sfere građana izražene negativnim zahtjevom suzdržavanja od povrede temeljnih prava, pripada i obveza afirmativnog djelovanja u svrhu njihove zaštite i unaprjeđenja. ${ }^{38}$ Stoga većina eksplicite konstitucionalizira socioekonomska prava, a tome u prilog ističe se "moralna defektnost", tj. neuspjeh ostvarenja moralne svrhe ustava ako mu nedostaju jamstva socijalnih prava. ${ }^{39}$ Njihova realizacija istovremeno ovisi o materijalnim mogućnostima i specifičnosti kulture te je ispravno tvrditi da socijalna prava "žive na pretpostavkama koje sama ne mogu osigurati”. ${ }^{40} \mathrm{U}$ tom se smislu pitanje financijske održivosti ističe kao točka prijepora s obzirom na to da će, ako se o njoj ne vodi računa, smanjenjem fiskalnih kapaciteta socijalna prava postati ugrožena i svedena na ispraznu formulaciju ustavotvorčevih želja. Nasuprot tome, isključivo vođenje ekonomskim interesima također ih prijeti ugroziti, u potpunosti ih podređujući ostvarenju financijske stabilnosti. ${ }^{41}$ Stoga je pri njihovoj zakonodavnoj konkretizaciji potrebno balansirati između dviju suprotstavljenih tendencija: nerazmjernog širenja socijalnih prava izvan okvira fiskalnih mogućnosti te pretjera-

33 Marcin Wujczyk, 'The Constitutionalisation of Social Security Rights as the Way to a Social Justice State' in Alexandre Egorov and Marcin Wujczyk (eds), The Right to Social Security in the Constitutions of the World: Broadening the Moral and Legal Space for Social Justice, vol 1 Europe (International Labour Organization 2016) 1 <https://www.ilo.org/wcmsp5/groups/public/--ed_norm/---normes/documents/publication/wcms_518153. pdf> pristupljeno 24. rujna 2021.

CESCR (n 30) para 8.

Ustav Republike Hrvatske (NN 85/2010 - pročišćeni tekst i 5/2014 - Odluka Ustavnog suda br SuP-O-1/2014 od 14. siječnja 2014.) (HR).

Smiljko Sokol, 'Hrvatska kao demokratska ustavna država' (1998) 35(3) Politička misao 113.

Vidi Odluku o objavljivanju mnogostranih međunarodnih ugovora kojih je Republika Hrvatska stranka na temelju notifikacija o sukcesiji (NN-MU 12/1993) (HR).

Arsen Bačić, 'Prava izgubljena u tranziciji' (2005) 42(1-2) Zbornik radova Pravnog fakulteta u Splitu 6.

Frank I Michelman, 'The constitution, social rights, and liberal political justification' (2003) 1(1) International Journal of Constitutional Law 22.

João Carlos Loureiro, 'Constitutionalism, welfare and crises' (2014) 1(3) e-Pública 56.

Ibid 53. 
nog ograničavanja u cilju održavanja fiskalne discipline. Pritom se isticanje potencijalne nemogućnosti ostvarenja socijalnih prava, kao argument protiv njihova uvrštenja u temeljna ljudska prava, zasniva na pogrešnoj presumpciji nužnosti potpune realizacije. Naime, trenutačna nemogućnost potpunog ostvarenja ne odriče im karakter prava, već apostrofira potrebu njihova kontinuiranog unaprjeđenja. ${ }^{42}$ Takvo shvaćanje odgovara supra iznesenom stavu CESCR-a o obvezi afirmativnog djelovanja u cilju progresivnog ostvarenja.

Unatoč općem prihvaćanju ljudskih prava kao neodvojivo povezanih i međuovisnih, socioekonomska prava i dalje su slabije zaštićena te je evidentno oklijevanje priznanja njihove utuživosti, što proizlazi iz shvaćanja kako su ona "samo puke deklaracije i k tome nezasitne raspoloživim resursima". ${ }^{43}$ Stoga neki ustavi, poput irskog ${ }^{44}$ i španjolskog, ${ }^{45}$ prave razliku između dvije generacije prava, priznajući građanskim i političkim status temeljnih ljudskih prava i otvarajući mogućnost sudske zaštite, dok socioekonomska definiraju kao principe socijalne i ekonomske politike upućene zakonodavcu, negirajući mogućnost njihova sudskog ostvarenja. ${ }^{46}$ Kritika utuživosti socijalnih prava je dvosmjerna i pretpostavlja nedostatak specifičnog stručnog znanja sudaca koje bi omogućilo potpuno razumijevanje financijskih implikacija priznanja pojedinih prava te smatra kako potencijal (pretjeranog) opterećenja proračuna priznanjem široke palete prava ta pitanja izdvaja iz sudske nadležnosti, čineći ih rezervatom demokratski izabranih grana vlasti (ponajprije zakonodavne). ${ }^{47}$ Prema takvom shvaćanju, poustavljenje socijalnih prava suce dovodi u položaj donositelja odluka sa značajnim posljedicama za prioritete raspodjele proračunskih sredstava utvrđene od strane zakonodavne i izvršne vlasti (suprotstavljajući odluku suda aktualnoj političkoj volji) ili pak pretjeranog samoograničavanja i ustupanja čitave sfere socijalnih (i ekonomskih) prava izabranim tijelima vlasti, otvarajući pritom mogućnost zapostavljanja pojedinih prava. ${ }^{48}$

Chilton i Versteeg zaključuju kako poustavljenje socijalnih prava nema izravan utjecaj na povećanje proračuna u svrhu osiguranja socijalnih prava i usluga, ne isključujući mogućnost pozitivnog djelovanja u smislu promijenjenog javnog narativa o socijalnim pravima, suzbijanja diskriminacije u njihovu ostvarenju ili prenamjene sredstava u cilju realizacije bez povećanja javne potrošnje. ${ }^{49}$ Slično, Ben-Bassat i Dahan dolaze do zaključka da ustavna socijalna prava uglavnom imaju slab utjecaj na veličinu javne potrošnje, ali pronalaze i donekle pozitivnu korelaciju između ustavnog prava na socijalnu sigurnost $\mathrm{i}$ javnih transfera (i stopa doprinosa socijalnog osiguranja)

42 Amartya Sen, 'Elements of a Theory of Human Rights' (2004) 32(4) Philosophy and Public Affairs 348.

43 Bačić (n 38) 13.

44 Čl. 45. irskog Ustava ističe kako su u njemu sadržana načela socijalne politike namijenjena Parlamentu (Oireachtas), kojem pripada isključiva nadležnost njihove implementacije te je isključena mogućnost njihove direktne sudske zaštite, Constitution of Ireland (1937, rev 2019) <https://www.const ituteproject.org/constitution/Ireland_2019?lang=en> pristupljeno 24. rujna 2021. (IE).

Čl. 53. st. 1. ističe kako načela priznata u 3. poglavlju (Vodeća načela ekonomske i socijalne politike) predstavljaju smjernice zakonodavstvu, sudskoj praksi i odlukama javnih vlasti, ali na njih se može pozvati pred redovnim sudovima isključivo u skladu sa (zakonskim) propisima koji ih implementiraju, Constitution of Spain (1978, rev 2011) <https://www.constituteproject.org/ constitution/Spain_2011?lang=en> pristupljeno 24. rujna 2021. (ES).

46 Ivana Tucak, ‘The Nature of Welfare Rights' [2016] 69-70 Dignitas 140-141.

47 Davis (n 18) 1023.

48 Michelman (n 39) 16.

49 Adam Chilton and Mila Versteeg, 'Rights without Resources: The Impact of Constitutional Social Rights on Social Spending' (2017) 60(4) Journal of Law and Economics 716. 
te između ustavnog prava na zdravlje i rezultata zdravstvenih politika. Kao razlog navode moguće preklapanje ustavnih jamstava i javnog izbora (engl. public choice) pri čemu ustavna socijalna prava mogu poslužiti organiziranijim društvenim skupinama (npr. starijima, umirovljenicima i sl.) pri utjecaju na javne politike. ${ }^{50}$ Pritom kao fokus analize uzimaju isključivo utjecaj ustavnog teksta na kreatore javnih politika, svjesno ignorirajući sudske interpretacije. ${ }^{51}$ Utoliko je apostrofirana važnost sudske zaštite socijalnih prava, s obzirom na nesigurnost njihova ostvarenja ukoliko su temeljena isključivo na predanosti političkih grana vlasti socijalnim vrijednostima ustava te na mogućnosti pritisaka određenih društvenih skupina (sukladno brojnosti i sposobnosti organiziranog djelovanja) na nositelje javnih politika u cilju povećanja vlastitih socijalnih prava, nauštrb drugih (potencijalno marginaliziranih i ranjivih) skupina.

Upravo se zaštita najranjivijih kroz jamstvo socijalnog minimuma izvedenog u praksi mnogih ustavnih sudova smatra ključnom u zaštiti od pretjeranog rastakanja socijalnih prava od strane zakonodavne vlasti, generiranog "dnevnim" potrebama i promjenjivim mogućnostima, štiteći pravo na osiguranje minimuma egzistencije dostojnog čovjeka. ${ }^{52} \mathrm{U}$ tom smislu Landau pohvalno govori o prvim godinama djelovanja kolumbijskog Ustavnog suda u kojima je afirmirao pravo odlučivanja o socijalnim pitanjima pružajući zaštitu "egzistencijalnog minimuma" najugroženijim skupinama, ali se kritički postavlja prema kasnijim populističkim stremljenjima da proširivanjem zaštite socijalnih prava na srednju i višu srednju klasu, suprotno utvrđenim politikama zakonodavne i izvršne vlasti, Ustavni sud proširi vlastiti legitimitet i time nadomjesti demokratski deficit. ${ }^{53}$ Proizlazi zaključak kako je sudska zaštita socijalnih prava neophodna za ostvarenje minimuma socijalnih potreba za dostojan život. Širenje socijalnih prava na srednju i višu srednju klasu također je potrebno, ali ne pripada zadaći (ustavnih) sudova, već ostaje pridržano zakonodavcu kao nositelju demokratskog legitimiteta. Sposobnost djelovanja u skladu $s$ temeljnim univerzalnim vrijednostima jača povjerenje građana u institucije demokratskoga poretka, a promoviranje solidarnosti redistributivnim politikama ${ }^{54}$ i proširivanje socijalnih prava od strane zakonodavca povećava legitimitet samog koncepta socijalne države, radije nego da bude instrumentalizirano u svrhu nadomještanja demokratskog deficita (ustavnih) sudova.

\section{SOCIJALNA ORIJENTIRANOST HRVATSKOG USTAVA}

URH prepoznaje nerazdvojivost $\mathrm{i}$ isprepletenost dviju generacija ljudskih prava, smještajući gospodarska, socijalna i kulturna ${ }^{55}$ zajedno s građanskim i političkim ${ }^{56}$ pravima u glavu

\footnotetext{
50 Avi Ben-Bassat and Momi Dahan, 'Social rights in the constitution and in practice' (2008) 36(1) Journal of Comparative Economics 118. Istraživanje je temeljeno na pet skupina socijalnih prava: socijalna sigurnost; obrazovanje; zdravlje; stanovanje; zaštita prava radnika, ibid 105-106.

Wujczyk (n 33) 4.

Vidi Landau (n 28) 207-221.

Davorka Matić, 'Demokracija, povjerenje i socijalna pravda' (2000) 31(3-4) Revija za sociologiju 191.

URH (n 35) čl. 48-70.

Ibid čl. 21-47.
} 
Ustava posvećenu zaštiti ljudskih prava i temeljnih sloboda. ${ }^{57}$ Unatoč tome, Ustavni sud Republike Hrvatske (u nastavku: USRH) u svojoj je praksi izveo razlikovanje dviju generacija ljudskih prava na temelju zakonskog oblika njihove razrade, izdvajajući socioekonomska prava iz sfere organskog zakonodavstva kojim se razrađuju ljudska prava i temeljne slobode, a čije donošenje zahtijeva podršku većine svih zastupnika u Hrvatskom saboru. ${ }^{58}$ Pritom USRH polazi sa stajališta pragmatičnosti, navodeći kako bi tumačenje definicije organskih zakona u dijelu koji se odnosi na ljudska prava, a koje bi obuhvaćalo sva prava i slobode pobrojane u Glavi III., rezultiralo smještanjem gotovo čitavog zakonodavstva u sferu organskih zakona, s obzirom na to da u praksi de facto nema zakona koji makar dijelom svojih odredaba ne zadire u sferu ljudskih prava i temeljnih sloboda. Posljedično, takvo bi tumačenje dovelo do brisanja granica između ordinarnog i organskog zakonodavstva te se "organskim zakonom kojim se razrađuju Ustavom utvrđena ljudska prava i temeljne slobode... ima... smatrati samo onaj zakon kojemu su temeljni predmet uređenja pojedino ili pojedina Ustavom utvrđena osobna i politička prava i slobode čovjeka" ${ }^{59}$ Posebno se problematičnim ističe shvaćanje USRH-a o mjerilima koja određuju karakter organskog zakona, pri čemu se valja "ograničiti na područje slobode, jednakosti i poštivanja prava čovjeka, kao temeljnih ustavnih vrednota propisanih u članku 3. Ustava. Njihov je sadržaj - za razliku od gospodarskih, socijalnih i kulturnih prava - određen samim Ustavom i individualiziran zajamčenom pravnom zaštitom na nacionalnoj i međunarodnoj razini" ${ }^{60}$ USRH time zanemaruje isprepletenost i nerazdvojivost dviju generacija ljudskih prava za ostvarenje demokratskih ideala (socijalne) slobode i jednakosti. Stoga se valja složiti s konstatacijom o nevaljanosti ponuđene argumentacije "koja, pozivajući se na temeljne vrednote ustavnog poretka RH, izvodi zaključak da formulacija 'poštivanje prava čovjeka' iz čl. 3. Ustava RH uključuje samo osobna i politička prava i slobode". ${ }^{61}$

Ostvarenje socijalnih prava zahtijeva potencijalno nedostatna javna sredstva te je stoga potrebna široka javna rasprava i snažan društveni nadzor nad njihovom alokacijom. Upravo zbog nedostatka demokratskog legitimiteta sudovi nevoljko pristupaju odlučivanju o socijalnim pravima, držeći ulogu političkih grana vlasti (ponajprije zakonodavne) primjerenijom vođenju javne rasprave te odlučivanju o sadržaju socijalnih prava i provođenju socijalnih politika. ${ }^{62}$ Snažne proračunske implikacije socijalnog zakonodavstva zahtijevaju širok demokratski konsenzus pri njegovu donošenju te se ističu dvije opasnosti koje proizlaze iz navedenog stajališta USRH-a. S jedne strane, dostatnost "obične" parlamentarne većine uz prisutnost kvoruma slabi pregovaračku poziciju te prijeti isključivanjem predstavnika manjinskih (i samim time posebno osjetljivih) skupina od odlučivanja i utjecaja na donošenje i sadržaj socijalnog zakonodavstva. S druge strane, postavlja se pitanje odnosi li se isključivanje socioekonomskih prava iz sfere ljudskih prava i temeljnih sloboda u smislu organskog zakonodavstva i

\footnotetext{
57 Ibid Glava III., čl. 14-70.

58 Ibid čl. 83., st. 2.

59 Odluka U-I-2566/2003 i U-I-2892/2003 USRH (27. studenoga 2003) (HR) t. 7.

6o Ibid t. 7

61 Sanja Barić, 'Zakonodavna delegacija i zakonski rezervat' (2006) 6(1) Hrvatska javna uprava 214.

62 Sanja Barić and Matija Miloš, 'Social Rights in the Republic of Croatia: Scattered to the Four Winds of Regulation' in Nada Bodiroga-Vukobrat, Siniša Rodin and Gerald Sander (eds), New Europe - Old Values? Reform and Perseverance (Springer 2016) 142.
} 
na mogućnost njihove zakonodavne delegacije. ${ }^{63}$ Naime, URH omogućava Hrvatskom saboru delegaciju dijela svoje zakonodavne funkcije Vladi Republike Hrvatske (u nastavku: Vlada), pod uvjetom da, inter alia, nije riječ o materiji kojom se razrađuju ljudska prava i temeljne slobode. ${ }^{64} \mathrm{~S}$ obzirom na supra izneseno stajalište USRH-a, proizlazi kako bi zakonodavna delegacija razrade socioekonomskih prava bila dopuštena. Takvo tumačenje kreira dvostruko "snižavanje" ustavnog položaja socioekonomskih prava: isprva ih izdvajajući iz sfere organskih zakona koji zahtjevom kvalificirane većine ipso facto pridonose ostvarenju načela demokratičnosti, potom omogućavajući parlamentu da delegira ovlast Vladi "da uredbama na temelju zakonske ovlasti zadire u gospodarska, socijalna i kulturna prava” te potonju mogućnost valja smatrati neprihvatljivom. ${ }^{65}$ Razumnim se, stoga, nameće prijedlog da se kriterij za razlikovanje materije organskog od ordinarnog zakonodavstva u praksi USRH-a izvede prema uzoru na teoriju esencije razvijenu u judikaturi njemačkog Saveznog ustavnog suda. Pritom bi isprva trebalo utvrditi "odnosi li se zakon u pretežitoj mjeri na ljudsko pravo ili temeljnu slobodu”, a potom "ulazi li u samu srž, samu bit dotičnog prava ili slobode”, pri čemu bi "[p]otvrdni odgovor na oba pitanja... ukazivao da se radi o materiji predviđenoj za regulaciju organskim zakonima". ${ }^{66}$

Iako valja pledirati za promjenu doktrine USRH-a u smjeru priznanja socijalnih prava punopravnim i jednakovrijednim ljudskim pravima u smislu zakonskog oblika njihove razrade, supra izneseno shvaćanje o zahtijevanom obliku socijalne legislacije apostrofira potrebu razvoja sveobuhvatne jurisprudencije USRH-a glede zaštite socijalnih prava. Stoga treba naglasiti kako URH dijeli mnoštvo karakteristika s većinom tranzicijskih ustava Srednje i Istočne Europe koji uključuju opširan katalog socioekonomskih prava, ne čineći razliku u mogućnosti njihova ustavnosudskog ostvarenja u odnosu na građanska i politička. ${ }^{67} \mathrm{U}$ zajedničkim odredbama primjenjivim na obje generacije konstitucionaliziranih prava i sloboda ${ }^{68}$ jamči jednakost pred zakonom i zabranjuje diskriminaciju, ${ }^{69}$ odmičući se pritom od koncepcije beziznimne jednakosti pred zakonom klasičnog liberalizma, koja ne uzima u obzir stvarne razlike između pojedinaca i društvenih skupina. U tom smislu, uz zabranu nejednakog postupanja s jednakima, radi ostvarenja legitimnih interesa i u službi promicanja prava i sloboda ranjivih skupina, dopušta mogućnost nejednakog postupanja s nejednakima, ${ }^{70} \mathrm{tj}$. pozitivnu diskriminaciju radi uravnoteženja formalne i faktične jednakosti.

Uvažavajući pravo zakonodavca da u skladu s prirodom potreba i okolnosti proširuje, odnosno sužava pojedina ustavna prava i slobode, uspostavlja mogućnost njihova ograničenja is-

\footnotetext{
63 Ibid 142-143.

64 URH (n 35) čl. 88., st. 1.

65 Barić (n 61) 215.

66 Sanja Barić i Amina Alijagić, 'Normativna djelatnost - izazov ostvarenju socijalnih prava' u Nada Bodiroga-Vukobrat i Sanja Barić (eds), Socijalna prava kao temeljna ljudska prava (TIM press 2010) 42-43.

67 Tucak (n 46) 142, 148; Ivana Tucak i Anita Blagojević, 'Welfare Rights in the Croatian Constitution' in Mario Vinković (ed), New Developments in EU Labour, Equality and Human Rights Law (Faculty of Law Osijek 2015) 284.

68 URH (n 35) čl. 14-20.

69 Ibid čl. 14.

70 Đorđe Gardašević, 'Ljudska prava i temeljne slobode u Ustavu RH’ u Josip Kregar i drugi (eds), Ljudska prava: uvod u studij (Pravni fakultet u Zagrebu 2014) 54.
} 
ključivo zakonom, radi zaštite legitimnog interesa, uz primjenu načela razmjernosti ${ }^{71}$ (upravo je navedeno načelo odigralo značajnu ulogu u recentnoj Odluci USRH-a u predmetu o zaštiti tzv. zaštićenih najmoprimaca, o čemu više infra). Time su postavljeni i uvjeti provođenja tzv. testa razmjernosti pri ocjeni ustavnosti pojedinog pravnog rješenja kojim se ograničavaju ljudska prava i slobode. Unatoč značaju testa razmjernosti u njihovoj zaštiti, njime je omogućen širok spektar diskrecije pri ocjeni ustavnosti pravnih akata te sama procjena postojanja legitimnog cilja, s obzirom na mogućnost širokog tumačenja njegova sadržaja, predstavlja osnovu široke interpretacije i sudskog aktivizma, ali istovremeno i opasnost političke zloupotrebe. ${ }^{72}$ Stoga je od ključnog značaja pripravnost Ustavnog suda da u svakom konkretnom slučaju (pro) cijeni političke posljedice određene odluke te se, sukladno tome, suzdrži od upuštanja u takva pitanja. ${ }^{73} \mathrm{U}$ tom se smislu ističe potreba opreza USRH u vezi s ustavnosudskim aktivizmom pri tumačenju pojedinih ustavnih odredbi i vođenja računa "o potrebi samoograničavanja i poštivanja doktrine o političkim pitanjima" ${ }^{74}$

Istovremeno, USRH mora voditi računa o opasnostima pretjeranog samoograničavanja. Osobito s obzirom na to da je njegova uloga u zaštiti ljudskih prava apostrofirana činjenicom što je jedino tijelo ovlašteno odrediti granice državnih ovlasti radi zaštite prava i pravnih načela te time političke odluke podvesti pod ustavnopravne zahtjeve, zadržavajući se pritom na ocjeni ustavnosti i ostajući neutralan prema odabranim politikama zakonodavca koje se kreću unutar ustavnih granica. ${ }^{75}$ Stoga je od najvećeg značaja mogućnost apstraktne ocjene ustavnosti zakona i drugih propisa ${ }^{76}$ te konkretne zaštite preko ustavne tužbe. ${ }^{77}$ Sukladno supra iznesenom, URH ne pravi razliku u mogućnosti ustavnosudske zaštite socioekonomskih prava u odnosu na građanska i politička. Ipak, jednaka mogućnost ne predmnijeva i jednak način i jačinu zaštite dviju generacija prava te se pri ocjeni suglasnosti s Ustavom zakona koji reguliraju socijalnu i gospodarsku materiju uobičajeno primjenjuje blaži test (poput kontrole racionalnosti). ${ }^{78}$

Pritom USRH nerijetko prati tendenciju europskih ustavnih sudova koji ocjenu suglasnosti zakona s ustavom radije provode na temelju opće ustavne odredbe o socijalnoj državi i pravdi, umjesto oslanjanja na konkretna socioekonomska prava. ${ }^{79}$ Stoga se valja zagledati u razvoj koncepta socijalne države i načela socijalne pravde u hrvatskoj ustavnosudskoj praksi.

71 Ibid 55; URH (n 35) čl. 16.

72 Đorđe Gardašević, 'Odnos prava i politike u realizaciji ljudskih prava’ u Nebojša Vučinić, Vedrana Spajić-Vrkaš i Siniša Bjeković (eds), Ljudska prava za nepravnike (Centar za ljudska prava Univerziteta Crne Gore 2003) 95.

73 Branko Smerdel, Ustavno uređenje europske Hrvatske (Narodne novine 2013) 450.

74 Ibid 451.

75 Vidi Duška Šarin, 'Ustavni sud Republike Hrvatske kao institucionalni zaštitnik ljudskih prava i temeljnih sloboda' (2015) 52(3) Zbornik radova Pravnog fakulteta u Splitu 760. te bilj. 23 na istoj stranici.

76 Ustavni zakon o Ustavnom sudu Republike Hrvatske (NN 49/2002 - pročišćeni tekst) (HR) čl. 35-61.

77 Ibid čl. 62-80.

78 Detaljnije o primjeni različitih standarda pri ocjeni ustavnosti u komparativnoj perspektivi vidi Đorđe Gardašević, 'Pojam temeljnih prava i Ustav Republike Hrvatske’ u Arsen Bačić (ed), Ustavi i demokracija: strani utjecaji i domaći odgovori (HAZU 2012) 297-299.

79 Arsen Bačić, 'O konstitucionalizaciji socijalnih prava i njihovu slabljenju prema sadržaju' [2013] 516=50 Rad Hrvatske akademije znanosti i umjetnosti. Razred za društvene znanosti 195.; Tucak and Blagojević (n 67) 286. 


\subsection{SADRŽAJ USTAVNOG KONCEPTA SOCIJALNE DRŽAVE I NAČELA SOCIJALNE PRAVDE TE ZAŠTITA SOCIJALNIH PRAVA U HRVATSKOJ USTAVNOSUDSKOJ PRAKSI}

Valja primijetiti kako njemački Temeljni zakon, ${ }^{80}$ kao jedan od nedvojbenih uzora hrvatskom ustavotvorcu, sadrži klauzulu socijalne države (čl. 20., st. 1.) koja ujedno predstavlja alternativu nepostojanju opširnog ustavnog kataloga socijalnih prava. Sama po sebi ona ne predstavlja individualno ljudsko pravo, ali zahvaljujući judikaturi Saveznog ustavnog suda nadilazi puko programatsko načelo te se promiče u konkretnu obvezu zakonodavca na poduzimanje širokog spektra mjera u cilju suzbijanja siromaštva, neopravdanih nejednakosti i neprihvatljivih razlika u dohocima, mirovinama i socijalnom statusu. ${ }^{81}$ Štoviše, Savezni ustavni sud odlazi korak dalje te pristupa kreaciji svojevrsnog novog ustavnog socijalnog prava na ostvarenje egzistencijalnog minimuma dostojnog čovjeka, izvodeći ga iz načela nepovredivosti ljudskog dostojanstva (čl. 1., st. 1.) i koncepta socijalne države (čl. 20., st. 1.). ${ }^{82}$ Time potvrđuje kako se načela pokazuju pogodnima za stvaranje novih ustavnih normi "usmjerenih na svoje 'konkretiziranje' ili ostvarivanje". ${ }^{83}$

Hrvatski ustavotvorac, konstitucionalizirajući koncept socijalne države ${ }^{84}$ smješta URH uz bok socijalno osjetljivim europskim ustavima, obvezujući zakonodavca na brigu o općem socijalnom blagostanju te progresivnom razvoju socijalnih prava u cilju ostvarenja države dobrobiti. Dodatno, načelo socijalne pravde ${ }^{85}$ uzdiže među najviše vrednote ustavnoga poretka koje ujedno predstavljaju temelj tumačenja Ustava. Upravo ustrajanje na uvjerenju o fundamentalnoj važnosti vrednota pri izgradnji države i društva smješta Republiku Hrvatsku u kontekst europskog i svjetskog poslijeratnog konsenzusa druge polovice 20. stoljeća, pri čemu sam "[p]roces ostvarivanja vrednota osigurava legitimnost [U]stava" ${ }^{86} \mathrm{Uz}$ doktrinarnu predanost ostvarenju vrednota kao temeljnih državnih načela, obvezujuća narav socijalne pravde kao esencijalnog dijela koncepta socijalne države proizlazi iz činjenice da u poustavljenom poretku zakonodavcu ne pripada sloboda odabira državnih ciljeva, već isključivo najprikladnijih sredstava ostvarenja ustavnih ciljeva. ${ }^{87} \mathrm{U}$ tom smislu USRH je relativno rano u svojoj praksi, potvrđujući pravo zakonodavca na uređenje socioekonomskih prava sukladno gospodarskim mogućnostima, istaknuo kako se time ne smiju ugroziti temeljna ustavna načela jednako-

80 Constitution of Germany (1949, rev 2014) <https://www.constituteproject.org/constitution/German_Federal_Republic_ 2014?lang=en> pristupljeno 24. rujna 2021. (DE).

81 Eberhard Eichenhofer, 'The Right to Social Security in the German Constitution' in Alexandre Egorov and Marcin Wujczyk (eds), The Right to Social Security in the Constitutions of the World: Broadening the Moral and Legal Space for Social Justice, vol 1 Europe (International Labour Organization 2016) 74 <https://www.ilo.org/wcmsp5/groups/public/---ed_norm/---normes/documents/ publication/wcms_518153.pdf> pristupljeno 24. rujna 2021.; Bačić (n 79) 193.

Detaljnije vidi Hartz IV (BVerfGE 125, 175), u: Tobias Zern and Martin Bauch (eds), Izbor odluka Ustavnog suda Savezne Republike Njemačke (Zaklada Konrad Adenauer 2015) 206-213. Vidi i Cindori i Kuzelj (n 2) 834.; Eichenhofer, ibid 76.

83 Riccardo Guastini, Sintaksa prava (Naklada Breza 2016) 194.

84 URH (n 35) čl. 1., st. 1.

85 Ibid čl. 3.

86 Arsen Bačić, 'Ustav Republike Hrvatske i najviše vrednote ustavnog poretka' (2012) 49(1) Zbornik radova Pravnog fakulteta u Splitu 17. 
sti, socijalne pravde i vladavine prava. ${ }^{88}$ Zbog apstraktne naravi socijalnih prava, pri ocjeni ustavnosti socijalnog zakonodavstva opetovano ističe širok spektar zakonodavne diskrecije pri utvrđivanju načina njihova ostvarenja, a što proizlazi iz činjenice da i sam ustavotvorac eksplicite prepušta uređenje određenih konstitucionaliziranih socijalnih prava zakonodavcu. ${ }^{89}$ USRH stoga zaključuje kako se ustavne odredbe o socijalnoj državi i pravdi te ustavna socijalna prava ne mogu neposredno primjenjivati bez prethodne zakonske (i potencijalno podzakonske) konkretizacije. Granicu kontrole ustavnosti socijalnog zakonodavstva predstavlja točka na kojoj se konstitucionalizacija socijalnih prava sukobljava s demokracijom, tj. na kojoj bi USRH, konkretizirajući ustavno jamstvo socijalnih prava ili sadržaj socijalne države i pravde, de facto preuzeo ulogu zakonodavca. Iz toga proizlazi nemogućnost ustavnosudske prosudbe svrsishodnosti odabranih mjera. ${ }^{90}$ Ista nipošto ne umanjuje obvezu zakonodavca na poduzimanje mjera, već mu ostavlja odabir onih koje drži najprikladnijima.

USRH je više puta potvrdio predanost socijalnoj državi kao fundacijskom elementu europskog konstitucionalizma, ističući kako ustavni karakter socijalnih prava upućuje na osnovne zahtjeve sadržane u konceptu socijalne države: provođenje pravedne i jednake redistributivne politike u cilju smanjenja ekstremnih nejednakosti te usklađivanje ograničenih resursa $s$ ustavnim socijalnim ciljevima. Temeljna socijalna prava pred nositelje vlasti postavljaju zahtjev zadovoljenja osnovnih potreba, neodvojivo povezanih s ostvarenjem dostojanstva ljudske osobe, a koje nadilaze egzistencijalni minimum (poput prava na obrazovanje). ${ }^{91}$ Načelo socijalne pravde kao temeljna vrednota i neodvojivi dio koncepta socijalne države nalaže uspostavljanje socijalno pravednoga poretka te je povrijeđeno u slučaju nedostatnosti osigurane pomoći ili zanemarivanja određenih društvenih skupina pri njezinu pružanju. ${ }^{92}$

U Odluci o ukidanju odredbi Zakona o mirovinskom osiguranju ${ }^{93}$ USRH je definirao pravnu narav prava na mirovinu u podsustavu mirovinskog osiguranja temeljenog na generacijskoj solidarnosti. Pritom je iz ustavnog prava zaposlenih i članova njihovih obitelji na socijalnu sigurnost i socijalno osiguranje ${ }^{94}$ izveo ustavnu obvezu uspostavljanja posebnog nacionalnog sustava socijalne sigurnosti i osiguranja ${ }^{95}$ te je pravo na mirovinsko osiguranje, iako ga URH eksplicite ne konstitucionalizira, utvrdio inherentnim pravu zaposlenih i članova njihovih obitelji na socijalno osiguranje i socijalnu sigurnost: "U tom smislu pravo na mirovinsko osiguranje ima ustavnu narav i pod zaštitom je Ustavnog suda." Iz tog zahtjeva proizlazi obveza drža-

88 Vidi Odluku U-I-283/1997 USRH (12. svibnja 1998.) (HR).

89 Vidi npr. URH (n 35) čl. 56., st. 1.

90 Vidi Odluku i Rješenje U-IP-3820/2009, U-IP-3826/2009 i dr. USRH (17. studenoga 2009.) (HR) t. 13.3.-13.4.

91 Ibid t. 13.1.

92 Vidi ibid t. 13.2.; Rješenje U-I-1694/2017 i dr. USRH (2. svibnja 2018.) (HR) t. 29.4.; Rješenje U-I-3685/2015 i dr. USRH (4. travnja 2017.) (HR) t. 26.3.

93 Zakon o mirovinskom osiguranju (NN 102/1998, 127/2000, 59/2001, 109/2001, 147/2002, 117/20003, 30/2004, 177/2004, 92/2005, 43/2007 - odluka Ustavnog suda, 79/20007, 35/2008) (HR).

94 URH (n 35) čl. 57., st. 1. (u Odluci citiran kao čl. 56., st. 1.).

95 "Iako Ustav ne propisuje izrijekom obvezu ustrojavanja posebnog sustava mirovinskog osiguranja u nacionalnom pravnom poretku, Ustavni sud ističe da je mirovinsko osiguranje inherentan dio 'socijalne sigurnosti i socijalnog osiguranja' (...) Stvaranjem takvog sustava država osigurava provođenje načela socijalne sigurnosti i pravde, koje između ostalih načela propisuje članak 3. Ustava, te funkcionira kao socijalna država što također između ostalog propisuje članak 1. Ustava. Stoga Ustavni sud utvrđuje da postoji ustavna obveza zakonodavca urediti prava zaposlenih i članova njihovih obitelji u okviru mirovinskog osiguranja kao središnje karike u lancu socijalne sigurnosti”, Odluka i Rješenje U-I-1988/1988 i dr. USRH (17. ožujka 2010.) (HR) t. 7. 
ve da ustroji katalog prava iz mirovinskog osiguranja, krug osiguranika, nadležno tijelo, sustav pravne zaštite i dr., a kako u odnosu na ta pitanja URH ne postavlja zahtjeve, cjelokupno uređenje tog sustava prepušteno je zakonodavcu. ${ }^{96}$ Pravo na socijalno davanje iz podsustava generacijske solidarnosti USRH određuje imovinskim pravom strogo osobne naravi s obilježjima javnopravnog davanja, a zakonodavac je pritom ovlašten samostalno mijenjati i prilagođavati njegovo uređenje sukladno gospodarskim i socijalnim prilikama. To ovlaštenje podliježe općim ustavnim ograničenjima, pri čemu eventualan gubitak dijela mirovine ili drugog mirovinskog davanja ne predstavlja "a priori narušavanje 'biti prava na mirovinu". ${ }^{97}$

Odlukom i Rješenjem ${ }^{98}$ o tzv. kriznom porezu $u^{99}$ USRH je priznao obvezujući značaj koncepta socijalne države i načela socijalne pravde, ${ }^{100}$ pobliže odredio njihov doseg i sadržaj te se na iznesena tumačenja opetovano pozivao u kasnijim odlukama. Ostavljajući krizni porez na snazi, instrumentalizirao je vrijedna doktrinarna razmatranja iznesena u tom predmetu. Pritom se pozvao na praksu njemačkog Saveznog ustavnog suda istaknuvši širok spektar normativne diskrecije zakonodavca pri uređenju poreznog sustava i obvezu samoograničavanja pri ocjeni ustavnosti poreznih zakona, pri čemu provjerava "samo poštovanje... vanjskih granica zakonodavčeve slobode (zabrana proizvoljnosti)" ${ }^{101}$ Dodatno, potrebom očuvanja određenih aspekata socijalne države ${ }^{102}$ opravdao je krajnje nesocijalnu mjeru suprotnu temeljnom opredjeljenju Republike Hrvatske kao socijalne države, načelu socijalne pravde te ustavnim načelima oporezivanja. ${ }^{103} \mathrm{U}$ Izdvojenom mišljenju suci Arlović i Matija sadržaj načela socijalne pravde, unatoč njegovoj apstraktnosti i promjenjivosti, pronalaze u mogućnosti njegova negativnog određenja, naime, utvrđivanjem što se ne može smatrati (socijalno) pravednim rješenjem. Ističu neprihvatljivom činjenicu da se oporezivanje ne obavlja u skladu s načelom ekonomske snage, što rezultira nesocijalnim zadiranjem u socijalni status poreznih obveznika. Stoga odbacuju konstataciju većine sudaca o kriznom porezu kao izrazu socijalne osjetljivosti, ${ }^{104} \mathrm{~s}$ obzirom na to da "o jednakosti građana pred zakonom... o jednakosti koju Ustav Republike Hrvatske stavlja na pijedestal najviših vrednota ustavnog poretka Republike Hrvatske, kao i o jednakosti i pravednosti u poreznim stvarima... ovdje nema ni govora" ${ }^{105}$ USRH u navedenom predmetu nije demonstrirao visoku razinu doktrinarnog samoograničavanja kao rezultat uva-

\footnotetext{
96 Ibid t. 12-12.1.

97 Vidi ibid t. 14.4., 14.6.-14.7.

98 Odluka i Rješenje U-IP-3820/2009, U-IP-3826/2009 i dr. USRH (17. studenoga 2009.) (HR).

99 Zakon o posebnom porezu na plaće, mirovine i druge primitke (NN 94/2009) (HR) i Zakon o posebnom porezu na primitke od samostalne djelatnosti i ostale primitke (NN 119/2009) (HR).

100 Vidi bilj. 91. i 92.

101 Odluka i Rješenje U-IP-3820/2009, U-IP-3826/2009 i dr. USRH (17. studenoga 2009.) (HR) t. 15.1.

102 "Zaključno, iako ZoPPPM ne doprinosi ujednačavanju socijalnih suprotnosti kao jednoj od temeljnih vrijednosti socijalne države, upravo taj Zakon otvara mogućnost da drugi aspekti socijalne države ostanu netaknuti u uvjetima gospodarske krize", ibid t. 13.5. U odnosu na izneseno, suci Arlović i Matija ispravno zaključuju kako o "ovako osjetljivoj stvari - socijalnoj pravdi, ne bi trebalo odlučivati prema motu 'cilj opravdava sredstvo!", Izdvojeno mišljenje sudaca Arlovića i Matije od 24. studenoga 2009., uz Odluku i Rješenje U-IP-3820/2009, U-IP-3826/2009 i dr. USRH (17. studenoga 2009.) (HR) t. I.

103 Ustavna načela oporezivanja vidi u čl. 51. URH-a (n 35); detaljnije o prijepornim pitanjima tzv. kriznoga poreza vidi Sonja Cindori i Valentino Kuzelj, 'Socijalni aspekt kriznoga poreza: Fiskalni instrument ili devijacija poreznog sustava?' (2018) 27 (2) Ekonomska misao i praksa 490-496; Bačić (n 79) 195-204; Tucak and Blagojević (n 67) 287-291.

104 Izdvojeno mišljenje sudaca Arlovića i Matije od 24. studenoga 2009., uz Odluku i Rješenje U-IP-3820/2009, U-IP-3826/2009 i dr. USRH (17. studenoga 2009.) (HR) t. I.

105 Ibid t. II.
} 
žavanja isključive sfere zakonodavnih ovlasti, već pretjeranu pasivnost prema zakonodavcu. Time je iznevjerio ulogu čuvara Ustava, propustio osnažiti ustavna načela oporezivanja te prepustio odluku o pravednosti kriznoga poreza isključivoj odluci građana u izbornom procesu. ${ }^{106}$ Pritom je zanemario najveću važnost socijalne uloge poreza, izraženu socijalno-političkim poreznim načelima (čl. 51.) kao jedinom eksplicite poustavljenom vrijednošću u vezi s oporezivanjem, kontekstualiziranom u odnosu na temeljno opredjeljenje hrvatskog ustavotvorca socijalnoj državi (čl. 1., st. 1.). ${ }^{107}$

Ocjenjujući ustavnost tzv. propisa o uskrati povlastica ${ }^{108}$ USRH je istaknuo da osiguranje minimuma ekonomskog blagostanja predstavlja pretpostavku ostvarenja ljudskog dostojanstva i naglasio ustavno pravo zaposlenih na zaradu dostatnu osiguranju dostojnog života, ${ }^{109}$ napominjući kako to pravo ne jamči određenu visinu ili pojedine elemente zarade (npr. uvećanje plaće). Također je ustvrdio kako povlastice određenim kategorijama zaposlenih u državnim, odnosno javnim službama, uređene kolektivnim ugovorima, nisu ustavne kategorije te su podložne promjenama na temelju suglasja ugovornih strana. Sukladno tome, istaknuo je značaj kolektivnog pregovaranja kao "temelja socijalnog dijaloga u društvu zasnovanom na vladavini prava” te dužnost obiju strana (sindikata i Vlade) da pregovaraju u dobroj vjeri. Paradoksalno, postupke Vlade koja je predlaganjem, odnosno donošenjem predmetnih propisa jednostrano uvela "privremenu uskratu" ugovorenih povlastica, opravdao je njezinom ustavnom obvezom brige o gospodarskom razvitku zemlje. ${ }^{110} \mathrm{Ne}$ odričući osnovanost prigovora o njezinu proceduralnom nepoštenju, ${ }^{111}$ navedene je propise ocijenio suglasnim Ustavu, s obzirom na nepovoljno gospodarsko stanje i privremeni karakter usvojenih mjera. ${ }^{112}$

Tucak i Blagojević zaključuju kako URH sadrži izdašan katalog socijalnih prava, a brojno i promjenjivo zakonodavstvo u okolnostima ekonomske krize podliježe značajnoj redukciji socijalnih prava, pri čemu je USRH naklonjen takvim legislativnim rješenjima. ${ }^{113}$ Analizirajući iznesenu tvrdnju valja uzeti u obzir recentniju praksu, ponajprije Rješenje o ocjeni ustavnosti tzv. zakona o konverziji kredita u švicarskim francima ${ }^{114}$ (u nastavku: zakoni o konverziji)

106 O međudjelovanju i isprepletenosti minimuma ustavnih zahtjeva pri oporezivanju te potencijalno veće razine porezne pravednosti kao izraza društvene volje izražene demokratskim načelom kroz rezultat izbornog procesa vidi Valentino Kuzelj, 〈Komplementarnost ustavnopravnih i društvenih odrednica porezne pravednosti u Republici Hrvatskoj〉 u Vuk Bevanda (ed), EMAN 2020 - Economics \& Management: How to Cope with Disrupted Times: Conference Proceedings (Association of Economists and Managers of the Balkan 2020) 469-475.

107 Hrvoje Arbutina, 'Ustavna i nadnacionalna ograničenja ovlaštenja na oporezivanje' (2012) 62 Zbornik Pravnog fakulteta u Zagrebu 1287-1288.

108 Zakon o uskrati prava na uvećanje plaće po osnovi ostvarenih godina radnog staža (NN 41/2014) (HR), Zakon o uskrati isplate pojedinih materijalnih prava zaposlenima u javnim službama (NN 143/2012) (HR) i Uredba o izmjenama i dopuni Zakona o uskrati isplate pojedinih materijalnih prava zaposlenima u javnim službama (NN 159/2013) (HR).

109 URH (n 35) čl. 56., st. 1. (u odlukama citiran kao čl. 55., st. 1.).

110 URH (n 35) čl. 110., alineja 7.

$111 \mathrm{U}$ tom smislu ističe načelno neprihvatljivim istovremeno kolektivno pregovaranje i ugovaranje određenih materijalnih prava te derogaciju ugovorenih prava u kratkom vremenskom roku zakonom, bez održavanja prethodnih pregovora o izmjenama kolektivnog ugovora te propituje "pošteno postupanje" Vlade na temelju činjenice da, unatoč važećim kolektivnim ugovorima, u prijedlogu državnog proračuna za 2014. godinu nije planirala sredstva za podmirenje preuzetih obveza.

112 Detaljnije vidi Odluka i Rješenje U-I-1625/2014 i dr. USRH (30. ožujka 2015.) (HR) t. 37. i dalje; Odluka U-I-4405/2013 i U-II3222/2014 USRH (31. ožujka 2015.) (HR) t. 21. i dalje.

113 Tucak and Blagojević (n 67) 292.

114 Zakon o izmjeni i dopunama Zakona o potrošačkom kreditiranju (NN 102/2015) (HR); Zakon o izmjeni i dopunama Zakona o kreditnim institucijama (NN 102/2015) (HR). 
u kojem USRH ponavlja predanost hrvatskog Ustava socijalnoj državi i socijalnoj pravdi, ali $\mathrm{i}$ ističe potrebu odmjeravanja potencijalno suprotstavljenih ustavnih vrijednosti: vlasničkih prava, poduzetničkih i tržišnih sloboda te zahtjeva proizišlih iz ideje države blagostanja. ${ }^{115} \mathrm{U}$ navedenom primjeru ostavio je na snazi zakone čiji je legitimni cilj smjerao olakšanju položaja dužnika u švicarskim francima kao posebno ranjive skupine. U Rješenju o ustavnosti tzv. lex Agrokora, ${ }^{116} \mathrm{u}$ cilju ispunjenja obveza proizišlih iz zahtjeva socijalne države, prepoznaje potrebu ostavljanja široke normativne slobode zakonodavcu pri uređenju gospodarske politike te izrijekom priznaje kako u "ustavnopravnoj teoriji važno mjesto zauzima doktrina ekonomske neutralnosti Ustava prema gospodarskim politikama i slobodi izbora zakonodavca". ${ }^{117} \mathrm{U}$ okviru tako shvaćene slobode izbora legislativnih rješenja, gospodarske mjere zakonodavca podliježu kontroli ustavnosti te iste moraju udovoljavati zahtjevima socijalne države, ustavnih i temeljnih prava te istovremeno biti sukladne s ustavnim jamstvom prava vlasništva te poduzetničkom slobodom i slobodom udruživanja. ${ }^{118}$

U Odluci o ustavnosti odredbi Zakona o najmu stanova, ${ }^{119}$ odlučujući o pravima tzv. zaštićenih najmoprimaca, USRH ukazuje na važnost ostvarenja ustavnog načela razmjernosti (čl. 16.). Pritom navodi da "odgovor na pitanje o (ne)razmjernosti zakonodavnog zahvata u pravo građana na dom i zaštitu njihovog privatnog, obiteljskog života - time i odgovor na pitanje je li zakonodavac zanemario Ustavom proklamirana načela socijalne države” ovisi o tome je li zakonodavac predvidio mjere u cilju "zaštite i potpore osobama koje će izgubiti posjed stanova i/ ili kao oblik kompenzacije za njihov gubitak” ${ }^{120}$ Time je, obiter dictum, vezao ispunjenje zadaća proizišlih iz ustavnog koncepta socijalne države (čl. 1., st. 1.) uz jamstvo nepovredivosti doma (čl. 34., st. 1.) te poštovanje i zaštitu osobnog i obiteljskog života (čl. 35.), a koji pripadaju katalogu osobnih i političkih prava i sloboda u strukturi URH-a. Iz navedenoga proizlazi neporeciva važnost ostvarenja minimuma socijalnih prava, kao konkretizacije općeg i temeljnog opredjeljenja hrvatskog ustavotvorca konceptu socijalne države, pri realizaciji građanskih i političkih prava i sloboda. Zahtjev ostvarenja socijalne slobode valja smatrati nerazdvojnim od šireg ustavnog postulata slobode i jednakosti (čl. 3.). Stoga USRH, ocjenjujući je li zakonodavac uspio udovoljiti pozitivnoj obvezi "zaštite općeg interesa zajednice koja uključuje i dostupnost zadovoljavajućeg smještaja za one u lošijem položaju”, ispravno zaključuje da je osporenim mjerama nametnut prekomjeran teret jednoj kategoriji građana (zaštićenim najmoprimcima), radi ostvarenja svrhe koja je "po svojoj naravi primarna obveza države". Iz navedenog proizlazi da takve mjere ne udovoljavaju zahtjevima načela razmjernosti. ${ }^{121}$

U Izdvojenom podupirućem mišljenju, suci Abramović, Kušan i Selanec naglašavaju potrebu promatranja međuodnosa vlasnika stanova i zaštićenih najmoprimaca kao trostranog, radije nego dvostranog odnosa. U takvom odnosu država kao treća strana ima ključnu ulogu u kompenzaciji vlasnika stanova zbog nemogućnosti mirnog uživanja vlastite imovine te vra-

\footnotetext{
115 Rješenje U-I-3685/2015 i dr. USRH (4. travnja 2017.) (HR) t. 26.2.-26.4.; vidi i Cindori i Kuzelj (n 2) 835.

116 Zakon o postupku izvanredne uprave u trgovačkim društvima od sistemskog značaja za Republiku Hrvatsku (NN 32/2017) (HR).

117 Rješenje U-I-1694/2017 i dr. USRH (2. svibnja 2018.) (HR) t. 29.5.

118 Ibid t. 29.6 .

119 Zakon o najmu stanova (NN 91/1996, 48/1998, 66/1998, 22/2006, 68/2018) (HR) i Zakon o izmjenama i dopuni Zakona o najmu stanova (NN 68/2018) (HR).

120 Odluka i Rješenje U-I-3242/2018 i dr. USRH (14. rujna 2020.) (HR) t. 32.1.

121 Ibid t. 32.5 .
} 
ćanju iste. S druge strane, država ima i obvezu iznalaženja odgovarajućeg rješenja problema zaštićenih najmoprimaca, ovisno o konkretnim okolnostima pojedinog slučaja. Ispravno ističu da "ako se na problem gleda kao na obvezu države da ispuni svoje obveze i prema vlasniku stana i prema zaštićenom najmoprimcu, tada problem više nije tako složen. On je možda skup, ali to više nije pravno pitanje o kojem ovisi ocjena ustavnosti”. ${ }^{122}$ Naposljetku, sutkinja Antičević Marinović u Izdvojenom mišljenju suglasnom s Odlukom napominje kako je postizanje ravnoteže između dvaju legitimnih interesa (stanara i vlasnika) nemoguće bez materijalne potpore države te da je država "de facto tu obvezu bila preuzela i već spomenutim zakonom, a... Republika Hrvatska definira se i kao socijalna država, dok je... socijalna pravda uzdignuta kao jedna od najviših vrednota našeg ustavnog poretka”. ${ }^{123}$ Navedeno svjedoči jasan stav USRH-a u vezi s aktivnom ulogom države u ostvarenju ciljeva države dobrobiti te neprihvaćanje ideje neoliberalnog "uskrsnuća” nesocijalne minimalne države, osnažujući tvrdnju "kako je socijalna država danas doista normativni zahtjev, dok iz ekonomske neutralnosti ustava proizlazi kako neograničeno tržište i država 'noćni čuvar' nisu temeljni postulat demokracije". ${ }^{124}$

\section{UMJESTO ZAKLJUČKA}

Potreba afirmativnog djelovanja u svrhu osiguranja socijalne sigurnosti kao preduvjeta ljudskog dostojanstva postaje imperativ suvremenih demokratskih poredaka. Navedeno potvrđuje Opća deklaracija UN-a, čija predanost socijalnoj sigurnosti i ljudskom dostojanstvu obvezujući oblik dobiva u odredbama ICESCR-a. Kao njegova stranka, Republika Hrvatska obvezala se aktivno sudjelovati u progresivnom ostvarenju u njemu sadržanih prava, do granica raspoloživih mogućnosti, s ciljem (postupne) potpune realizacije. Dodatno, hrvatski je ustavotvorac prihvatio sva gospodarska, socijalna i kulturna prava zajamčena ICESCR-om te ustavima razvijenih europskih demokracija. Time je stvorena dvostruka obveza (međunarodna i ustavna) hrvatskog zakonodavca na uspostavljanje socijalno pravednoga poretka.

USRH je u svojoj praksi, polazeći sa stajališta pragmatičnosti, izveo neopravdano razlikovanje između dviju generacija ljudskih prava i temeljnih sloboda u strukturi URH-a kad je riječ o zakonskom obliku njihove razrade. Navedeni stav prijeti daljnjim snižavanjem demokratičnosti i transparentnosti njihove konkretizacije potencijalnom i neprihvatljivom mogućnošću zakonodavne delegacije socijalnog zakonodavstva Vladi. Unatoč tome, nije dovedena u pitanje mogućnost ustavnosudske zaštite socijalnih prava.

Upravo suprotno, moguće je ustvrditi kako je USRH u relativno kratkom vremenu uspostavio impozantan niz doktrinarnih razmatranja o prirodi socijalne države i socijalnih prava. Stoga, u svjetlu recentnog razvoja ustavnosudske prakse glede zakona o konverziji, lex Agrokora te zaštićenih najmoprimaca, valja ponovno razmotriti iznesenu tvrdnju Tucak i Blagojević ${ }^{125}$ o

122 Izdvojeno podupiruće mišljenje sudaca Abramovića, Kušan i Selanca od 21. rujna 2020., u odnosu na Odluku i Rješenje U-I3242/2018 i dr. USRH (14. rujna 2020.) (HR).

123 Izdvojeno mišljenje sutkinje Antičević Marinović od 22. rujna 2020., suglasno s Odlukom i Rješenjem U-I-3242/2018 i dr. USRH (14. rujna 2020.) (HR).

124 Cindori i Kuzelj (n 2) 835.

125 Vidi bilj. 113. 
naklonosti USRH prema redukciji socijalnih prava. Naime, riječ je o pogrešnoj interpretaciji razloga u pozadini donošenja ranijih odluka. Naklonost USRH-a rastakanju socijalnih prava povlačila bi doktrinarnu predanost načelima (neo)liberalne paradigme, što u hrvatskoj ustavnosudskoj praksi nije slučaj. To jasno proizlazi iz Rješenja o zakonima o konverziji, čiji je rezultat bilo eklatantno interferiranje u tržišnu funkciju radi ispravljanja pretjeranih socijalnih nejednakosti uzrokovanih aprecijacijom švicarskog franka. Dodatno, u Odluci i Izdvojenim mišljenjima o zaštićenim najmoprimcima opetovano se naglašava nužnost proaktivne uloge države na socijalnom planu s ciljem iznalaženja uravnoteženog rješenja, s posebnim obzirom prema položaju slabije strane (zaštićenih najmoprimaca). Naprotiv, predanost USRH-a nedvojbeno počiva na ideji socijalne pravde kao fundacijskog elementa europskog konstitucionalizma. Nedvojbeno je kako socijalna država ne predstavlja izraz ustavnog larpurlartizma, već pozitivnu obvezu zakonodavca i zahtjev ostvarenja socijalne sigurnosti građana. Konkretizacija njezina sadržaja prepuštena je javnom izboru izraženom kroz načelo demokracije, a ustavnosudska se kontrola nameće nužnom radi osiguranja minimuma socijalnih prava potrebnih za ostvarenje ljudskog dostojanstva.

Unatoč tome, uočljiva je pretjerana pasivnost USRH-a prema političkim granama vlasti (ponajprije parlamentu) koja ne proizlazi iz kategoričkog shvaćanja socijalnih prava kao rezervata zakonodavne diskrecije. Nije riječ, naime, o doktrinarnoj pasivnosti USRH-a prema izboru ekonomskih i socijalnih politika, već o pasivnosti prema samim političkim granama vlasti. Stoga treba voditi računa, osobito glede socijalnih prava, o zahtjevima "da se pojam i zaštita temeljnih prava na određeni način 'emancipira' od (obične, tradicionalne i povijesno 'liberalne') parlamentarne supremacije, u čemu valjanu ulogu jednako moraju imati i predstavnička (striktno demokratska) i najviša (ustavno)sudska tijela". ${ }^{126}$

\section{BIBLIOGRAFIJA}

1. Andrassy J i drugi, Međunarodno pravo, vol 1 (Školska knjiga 2010)

2. Arbutina H, 'Ustavna i nadnacionalna ograničenja ovlaštenja na oporezivanje' (2012) 62 Zbornik Pravnog fakulteta u Zagrebu 1283

3. Bačić A, 'O konstitucionalizaciji socijalnih prava i njihovu slabljenju prema sadržaju' [2013] 516=50 Rad Hrvatske akademije znanosti i umjetnosti. Razred za društvene znanosti 187

4. Bačić A, 'Prava izgubljena u tranziciji' (2005) 42(1-2) Zbornik radova Pravnog fakulteta u Splitu 1

5. Bačić A, 'Ustav Republike Hrvatske i najviše vrednote ustavnog poretka' (2012) 49(1) Zbornik radova Pravnog fakulteta u Splitu 1

6. Barić S i Alijagić A, 'Normativna djelatnost - izazov ostvarenju socijalnih prava' u Nada Bodiroga-Vukobrat i Sanja Barić (eds), Socijalna prava kao temeljna ljudska prava (TIM press 2010) 30-55

7. Barić $S$ and Miloš M, 'Social Rights in the Republic of Croatia: Scattered to the Four Winds of Regulation' in Nada Bodiroga-Vukobrat, Siniša Rodin and Gerald Sander (eds), New Europe - Old Values? Reform and Perseverance (Springer 2016) 137-63

8. Barić S, 'Zakonodavna delegacija i zakonski rezervat' (2006) 6(1) Hrvatska javna uprava 191 
9. Ben-Bassat A and Dahan M, 'Social rights in the constitution and in practice' (2008) 36(1) Journal of Comparative Economics 103

10. Chilton A and Versteeg M, 'Rights without Resources: The Impact of Constitutional Social Rights on Social Spending' (2017) 60(4) Journal of Law and Economics 713

11. Cindori S i Kuzelj V, 'Exemplis discimus: Reafirmacija vrijednosti i redefinicija sadržaja socijalne države u novom stoljeću' (2019) 40(2) Zbornik Pravnog fakulteta Sveučilišta u Rijeci 823

12. Cindori S i Kuzelj V, 'Socijalni aspekt kriznoga poreza: Fiskalni instrument ili devijacija poreznog sustava?' (2018) 27 (2) Ekonomska misao i praksa 479

13. Davis DM, 'Socio-economic rights: has the Promise of Eradicating the Divide Between First and Second Generation Rights Been Fulfilled?' in Tom Ginsburg and Rosalind Dixon (eds), Comparative Constitutional Law (Edward Elgar 2011) 519

14. Davis DM, 'Socio-economic Rights' in Michel Rosenfeld and András Sajó (eds), The Oxford Handbook of Comparative Constitutional Law (OUP 2012) 1020

15. De Geus A, Thode E and Weidenfeld C, Europe Reforms Labour Markets: Leaders' Perspectives (De Gruyter 2016)

16. Eichenhofer E, 'The Right to Social Security in the German Constitution' in Alexandre Egorov and Marcin Wujczyk (eds), The Right to Social Security in the Constitutions of the World: Broadening the Moral and Legal Space for Social Justice, vol 1 Europe (International Labour Organization 2016) $72<$ https:// www.ilo.org/wcmsp5/groups/public/---ed_norm/---normes/documents/ publication/wcms_518153. pdf> pristupljeno 24. rujna 2021.

17. Fukuyama F, 'Kraj povijesti?' (1990) 27(2) Politička misao 171

18. Gardašević Đ, 'Ljudska prava i temeljne slobode u Ustavu RH’ u Josip Kregar i drugi (eds), Ljudska prava: uvod u studij (Pravni fakultet u Zagrebu 2014) 51-60

19. Gardašević Đ, 'Odnos prava i politike u realizaciji ljudskih prava' u Nebojša Vučinić, Vedrana Spajić-Vrkaš i Siniša Bjeković (eds), Ljudska prava za nepravnike (Centar za ljudska prava Univerziteta Crne Gore 2003) 87-98

20. Gardašević Đ, 'Pojam temeljnih prava i Ustav Republike Hrvatske’ u Arsen Bačić (ed), Ustavi i demokracija: strani utjecaji i domaći odgovori (HAZU 2012) 285-310

21. Graf Kielmansegg P, 'Budućnost demokracije' (2002) 39(2) Politička misao 106

22. Grande E, 'Od nacionalne države do transnacionalnoga režima politike - državna upravljačka sposobnost u globalizacijskome razdoblju' (2002) 39(2) Politička misao 92

23. Grant E, 'Human Dignity and Socio-Economic Rights' (2012) 33(3) Liverpool Law Review 235

24. Greve B, 'Future of the welfare state?' in Bent Greve (ed), Routledge Handbook of the Welfare State (2nd edn, Routledge 2019) 525-533

25. Guastini R, Sintaksa prava (Naklada Breza 2016)

26. Koprić I i drugi, Upravna znanost: javna uprava u suvremenom europskom kontekstu (Pravni fakultet u Zagrebu 2014)

27. Kregar J, 'Legitimnost prava' (2011) 5(1) Studia lexicographica 17

28. Kuzelj V, 'Komplementarnost ustavnopravnih i društvenih odrednica porezne pravednosti u Republici Hrvatskoj' u Vuk Bevanda (ed), EMAN 2020 - Economics \& Management: How to Cope with Disrupted Times: Conference Proceedings (Association of Economists and Managers of the Balkan 2020) 469-475

29. Landau D, 'The Reality of Social Rights Enforcement' (2012) 53(1) Harvard International Law Journal 190 
30. Loureiro JC, 'Constitutionalism, welfare and crises' (2014) 1(3) e-Pública 41

31. Matić D, 'Demokracija, povjerenje i socijalna pravda' (2000) 31(3-4) Revija za sociologiju 183

32. Michelman FI, 'The constitution, social rights, and liberal political justification' (2003) 1(1) International Journal of Constitutional Law 13

33. Miličić V, Opća teorija prava i države (Vlastita naklada 2008)

34. Perić B, Struktura prava (Informator 1994)

35. Pusić E, 'Može li se država još opravdati?' (2002) 39(2) Politička misao 71

36. Pusić E, 'Odnos ljevice prema državi' (1996) 33(2-3) Politička misao 47

37. Pusić E, Upravne organizacije: interakcija - struktura - interes (Društveno veleučilište u Zagrebu 2005)

38. Reinhard W, 'Čemu nas o budućnosti države poučava njezina povijest?' (2002) 39(2) Politička misao 15

39. Sen A, 'Elements of a Theory of Human Rights' (2004) 32(4) Philosophy and Public Affairs 315

40. Smerdel B, Ustavno uređenje europske Hrvatske (Narodne novine 2013)

41. Sokol S, 'Hrvatska kao demokratska ustavna država' (1998) 35(3) Politička misao 112

42. Šarin D, «Ustavni sud Republike Hrvatske kao institucionalni zaštitnik ljudskih prava i temeljnih sloboda> (2015) 52(3) Zbornik radova Pravnog fakulteta u Splitu 755

43. Tucak I, 'The Nature of Welfare Rights' [2016] 69-70 Dignitas 133

44. Tucak I and Blagojević A, 'Welfare Rights in the Croatian Constitution' in Mario Vinković (ed), New Developments in EU Labour, Equality and Human Rights Law (Faculty of Law Osijek 2015) 267-93

45. Voigt R, 'Koliko nam države treba?' (2002) 39(2) Politička misao 27

46. Vrban D, Država i pravo (Golden marketing 2003)

47. Wujczyk M, 'The Constitutionalisation of Social Security Rights as the Way to a Social Justice State' in Alexandre Egorov and Marcin Wujczyk (eds), The Right to Social Security in the Constitutions of the World: Broadening the Moral and Legal Space for Social Justice, vol 1 Europe (International Labour Organization 2016) 1 <https://www.ilo.org/wcmsp5/groups/public/---ed_norm/---normes/documents/publication/cms_518153.pdf> pristupljeno 24. rujna 2021.

48. Zern $\mathrm{T}$ and Bauch M (eds), Izbor odluka Ustavnog suda Savezne Republike Njemačke (Zaklada Konrad Adenauer 2015)

\section{PROPISI I DOKUMENTI}

1. CESCR General Comment No 19: The right to social security (art 9), 4 February 2008, E/C.12/ GC/19

2. CESCR General Comment No 3: The Nature of States Parties' Obligations (art 2 para 1 of the Covenant), 14 December 1990, E/1991/23

3. CESCR General Comment No 9: The domestic application of the Covenant, 3 December 1998, E/C.12/1998/24

4. Constitution of Germany (1949, rev 2014) <https://www.constituteproject.org/constitution/German_Federal_Republic_2014?lang=en > pristupljeno 24. rujna 2021. (DE)

5. Constitution of Ireland (1937, rev 2019) <https://www.constituteproject.org/constitution/Ireland_2019?lang=en> pristupljeno 24. rujna 2021. (IE) 
6. Constitution of Spain (1978, rev 2011) <https://www.constituteproject.org/constitution/ Spain_2011?lang=en> pristupljeno 24. rujna 2021. (ES)

7. International Covenant on Economic, Social and Cultural Rights, (1983) UNTS vol 993

8. Odluka o objavi Opće deklaracije o ljudskim pravima (NN-MU 12/2009) (HR)

9. Odluka o objavljivanju mnogostranih međunarodnih ugovora kojih je Republika Hrvatska stranka na temelju notifikacija o sukcesiji (NN-MU 12/1993) (HR)

10. Uredba o izmjenama i dopuni Zakona o uskrati isplate pojedinih materijalnih prava zaposlenima u javnim službama (NN 159/2013) (HR)

11. Ustav Republike Hrvatske (NN 85/2010 - pročišćeni tekst i 5/2014 - Odluka Ustavnog suda br SuP-O-1/2014 od 14. siječnja 2014.) (HR)

12. Ustavni zakon o Ustavnom sudu Republike Hrvatske (NN 49/2002 - pročišćeni tekst) (HR)

13. Zakon o izmjenama i dopuni Zakona o najmu stanova (NN 68/2018) (HR)

14. Zakon o izmjeni i dopunama Zakona o kreditnim institucijama (NN 102/2015) (HR)

15. Zakon o izmjeni i dopunama Zakona o potrošačkom kreditiranju (NN 102/2015) (HR)

16. Zakon o mirovinskom osiguranju (NN 102/1998, 127/2000, 59/2001, 109/2001, 147/2002, 117/20003, 30/2004, 177/2004, 92/2005, 43/2007 - odluka Ustavnog suda, 79/20007, 35/2008) (HR)

17. Zakon o najmu stanova (NN 91/1996, 48/1998, 66/1998, 22/2006, 68/2018) (HR)

18. Zakon o posebnom porezu na plaće, mirovine i druge primitke (NN 94/2009) (HR)

19. Zakon o posebnom porezu na primitke od samostalne djelatnosti i ostale primitke (NN 119/2009) (HR)

20. Zakon o postupku izvanredne uprave u trgovačkim društvima od sistemskog značaja za Republiku Hrvatsku (NN 32/2017) (HR)

21. Zakon o uskrati isplate pojedinih materijalnih prava zaposlenima u javnim službama (NN 143/2012) (HR)

22. Zakon o uskrati prava na uvećanje plaće po osnovi ostvarenih godina radnog staža (NN 41/2014) (HR)

\section{PRESUDE I DRUGE ODLUKE}

1. Izdvojeno mišljenje sudaca Arlovića i Matije od 24. studenoga 2009., uz Odluku i Rješenje U.IP3820/2009, U-IP-3826/2009 i dr. USRH (17. studenoga 2009.) (HR)

2. Izdvojeno mišljenje sutkinje Antičević Marinović od 22. rujna 2020., suglasno s Odlukom i Rješenjem U-I-3242/2018 i dr. USRH (14. rujna 2020.) (HR)

3. Izdvojeno podupiruće mišljenje sudaca Abramovića, Kušan i Selanca od 21. rujna 2020., u odnosu na Odluku i Rješenje U-I-3242/2018 i dr. USRH (14. rujna 2020.) (HR)

4. Odluka i Rješenje U-I-1625/2014 i dr. USRH (30. ožujka 2015.) (HR) 
5. Odluka i Rješenje U-I-1988/1988 i dr. USRH (17. ožujka 2010.) (HR)

6. Odluka i Rješenje U-I-3242/2018 i dr. USRH (14. rujna 2020.) (HR)

7. Odluka i Rješenje U-IP-3820/2009, U-IP-3826/2009 i dr. USRH (17. studenoga 2009) (HR)

8. Odluka U-I-2566/2003 i U-I-2892/2003 USRH (27. studenoga 2003.) (HR)

9. Odluka U-I-283/1997 USRH (12. svibnja 1998.) (HR)

10. Odluka U-I-4405/2013 i U-II-3222/2014 USRH (31. ožujka 2015.) (HR)

11. Rješenje U-I-1694/2017 i dr. USRH (2. svibnja 2018.) (HR)

12. Rješenje U-I-3685/2015 i dr. USRH (4. travnja 2017.) (HR) 


\section{APOTHEOSIS OF THE SOCIAL STATE: THE IMPERATIVE OF ACHIEVING SOCIAL JUSTICE IN THE REPUBLIC OF CROATIA}

\section{Summary}

By deliberate choice of the Croatian constitution-makers, the Constitution of the Republic of Croatia protects all economic, social and cultural rights guaranteed by constitutions of developed European democracies and by the International Covenant on Economic, Social and Cultural Rights to which Croatia is a party. This creates a dual (constitutional and international) obligation for the Croatian legislature to establish a socially just order. Although the constitutional text places both of the human rights generations within the same title, the constitutional jurisprudence adopted a position, whereby socioeconomic rights are excluded from the sphere of organic laws used to elaborate the constitutionally guaranteed fundamental rights and freedoms. This development notwithstanding, the potential of their protection before the Constitutional Court has not been reduced, as the Court has developed an impressive list of doctrinal positions on the nature of social rights, committing to the concept of social state as a foundational element of European constitutionalism. Still, we would be remiss if we did not emphasize the Constitutional Court's passive stance towards the political branches of the government regarding the social rights and must therefore plead for a more active approach in that regard.

Keywords: $\quad$ social state, social justice, human rights, Constitution of the Republic of Croatia, Constitutional Court of the Republic of Croatia

\section{(c) (1) (\$)}

This work is licensed under a Creative Commons

Attribution-NonCommercial 4.0 International License.

\footnotetext{
Valentino Kuzelj, Student at the Faculty of Law, University of Zagreb, Trg Republike Hrvatske 14, 10000 Zagreb. E-mail address: valentino.kuzelj01@gmail.com. ORCID: https://orcid.org/0000-0003-3028-8562.

** Sonja Cindori, PhD, Associate Professor, Faculty of Law, University of Zagreb, Trg Republike Hrvatske 14, 10000 Zagreb. E-mail address: sonja.cindori@pravo.hr. ORCID: https://orcid.org/0000-0002-0134-9285.

*** Ana Horvat Vuković, PhD, Associate Professor, Faculty of Law, University of Zagreb, Trg Republike Hrvatske 14, 10000 Zagreb. E-mail address: ana.horvat@pravo.hr. ORCID: https://orcid.org/0000-0002-8451-5620.
} 